\title{
J. Cilliers
}

\section{THE ABSENCE OF PRESENCE.} HOMILETICAL REFLECTIONS ON LUTHER'S NOTION OF THE MASKS OF GOD (LARVAE DEI)

\section{ABSTRACT}

This paper addresses a complex but core issue of preaching, namely the experience of the elusiveness of God's presence (revelation) by taking cognisance of the notion of masking. Besides being a common cultural phenomenon, the art of masking could also be evaluated theologically and therefore homiletically. Luther's understanding of the masks of God (larvae dei) is introduced into the discussion, and a number of homiletical implications are drawn in view of the continuous tension that exists between God's revealing and his concealing.

\section{THE PROBLEM AND PROMISE OF PRESENCE}

The major promise of all preaching hinges on the question of God's presence; the major problem of all preaching hinges on God's absence. This tension forms the alpha and omega of all our homiletical endeavours (Bohren 1972:7). Bohren refers to the silence of God (which he links to his absence) and concludes:

Unser problem ist vor allem die Abwesenheit Gottes in unserem Reden von Gott, dass wir von inm reden, während er sich verschweigt (1972:33).

This being said, the curious (but theological) fact remains that it is not always easy to distinguish between God's presence and his absence.

Prof. Johan Cilliers, Department Practical Theology and Missiology, University of Stellenbosch.E-mail: jcilliers@sun.ac.za 
Often his absence is perceived as presence, and his presence as absence. Often his words become silent, but this silence still speaks. The prayer of Kierkegaard in this regard remains classic:

Father in heaven! You speak to humans in many ways: You, to whom all wisdom and intellect belongs, You wish to make Yourself conceivable to us anew. Oh, and also when You remain silent, then You still indeed speak to us; because also He who speaks sometimes remains silent to give his children the opportunity to have their say; also He that speaks sometimes remains silent to test his beloveds; also He who speaks sometimes remains silent to make the moment of understanding so much more profound when it comes. Father in heaven, is this not so? Oh, the time of silence, when a person stands alone and deserted, because we do not hear Your voice, then we feel that the separation will be forever. Oh, the time of silence, when a person thirsts in the desert, because we do not hear Your voice, and it seems as though we have been entirely forgotten! Father in heaven, then it is but a short pause in the coherence of the dialogue between You and us. So allow this also to be blessed, this silence of Yours, like every word of Yours to us. Do not let us forget that You also then speak, when You are silent; give us this consolation: that you remain silent out of love, just as You also speak out of love, so that now, whether You are silent and whether You speak, You are still the same Father, who acts with the same Fatherliness, whether you now lead us through Your voice, and whether You now teach us with Your silence (Kierkegaard 1949:210).

It is important to note that these experiences of the modes of God's revelation are exactly that: existential experiences of presence and absence, and silence and hearing. Silence and absence are categories of experience linked especially to the question of suffering and the crises of faith. Therefore, it does not intend to make ontological statements about the "nature" of God but rather functions as existential issues in need of interpretation and therefore hermeneutics. Although one could distinguish between categories such as "absence" or "silence" or "concealment", the common denominator in all of them is the experience of God's "distance" - a fact that calls for discernment, for wisdom (sapientia).

In our experience, one could say that God's presence often remains elusive (Terrien 1978:476). It could indeed be said that, even in Old Testament times, the experience of God's presence often leads to a flight towards his absence; and his absence often towards a plea for his presence - Psalm 139 is a classic example: 
Lord, where shall I flee from You...? (cf. verse 7)

Lord, I now flee to You...! (cf. verse 23)

The following seems to have been the common experience of many believers in ancient times:

Even starved for transcendence, most of the pious were in dread of divine nearness. Even begging for a respite, they were in fact asking for a deeper communion (Terrien 1978:326).

This dynamic relationship between our experiences of presence and absence or between revealing and concealing indeed forms the major problem and promise of preaching. It is my contention that this complex and multi-layered issue could be discussed fruitfully in terms of the concept of masking.

\section{MASKING AS REVEALING AND CONCEALING}

Perhaps the role of preaching could indeed be described as an act of unmasking, understood here in the light of the abovementioned need for hermeneutics and therefore sapientia. Of course, the phenomenon of masking is as old as humanity itself, taking on many diverse (literal and figurative) forms in many cultures. Briefly put, it could be said that masks conceal (veil), but surprisingly enough, also reveal (unveil). This needs some further clarification, especially if the role of the preacher is connected (theologically) to the phenomenon of masking. Preaching as an act of unmasking helps to reveal and conceal in at least two ways:

First, in the conventional sense of the word, the reality of the "real" person or persons behind the mask is unveiled. In this perspective, "mask" is seen as the "unreal", outer layer, hiding the true self. However, when preaching discloses humanity with all its flaws, masks are dropped and humanity is brought to light in all its nakedness before God. Unmasking here entails rehumanizing. This is already of paramount importance, of course, but the act of re-humanizing through unmasking goes even deeper.

Therefore, second, it is an interesting fact that masks were (and still are) used in many cultures, not only to hide own identity, but also to gain power. In many cultures, masking is identical to empowering. With the mask comes the power of the gods, or nature (animals), or ancestors, or whatever the cultural case might be. In this sense, the mask not only hides away (conceals), but also reveals another world, another dimension. Through the mask, a higher, more powerful sphere is sought after in many cultural rituals. Many of these 
rituals take place in times of transition and in rites of passage; therefore, in experiences of liminality (cf. Van Gennep 1909:33, 72).

In some of their ceremonies, the Celts of old for instance wore masks during the transition from and old to a new year. The medieval knights wore iron masks not only to hide their identities, but also to instil fear in the enemy. Many African tribes wear masks to approach the numinous, and so we could go on. The underlying principle in many of these acts of masking, however, remains the need for power. When the mask is taken away, power is lost. Unmasking equals disempowering.

Of course, masking-for-power is not only limited to the so-called primitive tribes, and it need not necessarily entail literal masks. Powers such as colonisation, apartheid, patriarchal notions, materialism, etc. all come with a mask. Often we do not even realise that we wear them. We play our role according to the mask (persona) that is required of us. One is reminded of Shakespeare's Macbeth, who boldly declares:

\author{
Life's but a walking shadow, a poor player \\ that struts and frets his hour upon the stage \\ and then is heard no more. It is a tale \\ told by an idiot, full of sound and fury, \\ signifying nothing. (Act 5; scene 5; lines 22-31).
}

We act according to the sphere of power in which we (choose to) live, i.e. we wear the masks that suit our (quest for) power best and that in fact empower us best. At least, we do this under the impression (illusion) that it does.

When preaching confronts these masks of power, it reveals not only the true person behind the mask, but also the power or destructive ideology represented in and through the mask. It is a deepened unmasking: The true identity of the mask itself is revealed. This brings us to yet another level of unmasking, calling for a deeper theological interpretation.

\title{
3. LUTHER: LARVAE DEI
}

Not only humans wear masks; God (in our experience) also does. In this regard, the insights of the Reformer Martin Luther come to our aid. ${ }^{1}$ Luther struggled intensely with experiences of a "distant" God. To Luther, God's concealment (as deus absconditus) was a burning existential question: How

1 It is impossible to do justice to the richness of Luther in this regard. What follows are merely a few strains of thought from Luther relevant to our subject. 
can I experience (find) God in the light of my despair and uncertainty? The "absence" of God lay on the level of his despair, but to Luther it was a "delicious despair" at the same time. By experiencing the "delicious despair" of existential struggles (Anfechtung), we are taught to trust in God alone. Fleeing to this (in our experience apparently absent) God, indeed in fleeing to God against God (ad deum contra Deum), we come to trust God, as known in the cross of Christ (cf. McGrath 1985:171-173). Luther's comments on the modes of God's revelation should indeed be understood on an existential level, as language of the heart ("Rhetorik des Herzens"; cf. Stolt 2000:49-61). Only through the language of the heart the struggle (Anfechtung) to discern God's presence, even and especially when God is seemingly absent, can be expressed.

In Luther's theology, one finds this constant tension between the act of God's revelation and the need to interpret and express this act in human terminology (for instance through preaching). In this sense, preaching as an act that unmasks concealed identities and misuse of power could be seen as a direct consequence of God's acts of unmasking, of bringing the darkness to light. These acts of unmasking (revelation) can be seen throughout salvation history, with the apex in the Christ event that tears the curtain of the tabernacle to reveal the innermost sanctuary, and it can be seen especially in the outpouring of the Spirit on the day of Pentecost. Ultimately, it is the Spirit that opens and enlightens our eyes to discern God's presence, also in the act of preaching (cf. Eph. 1:15-21; also Stolt 2000:73).

It is a known fact that Luther often spoke of God's acts and presence in history as a disguise or mask (reminiscent of Calvin's mirror metaphor that reveals but also conceals; cf. Neven, 2009: 80; also Van der Kooi 2002:22). According to Luther, every part of creation forms part of God's masquerade (Ideo universa creatura eius est larva dei; W.A. 40:1:174; 17: II: 192). God is always present and always working. God not only created this world; it also represents God, and could be compared to a cloth with which God covers himself.

There is no discrepancy here: God's complete transcendence is his absolute immanence. He is present in every leaf on every tree and in every piece of bread that we eat, and at the same time, he is above and beyond all that is. The whole of history is God's great masquerade, and God's masks (larvae del) can take on many forms: the church, preachers, but also kings and queens, ordinary working people, positive but also destructive powers. Even the devil and God's own judgment can mask the acts of God's love. The powers that destruct, however, do not understand that their actions cannot nullify God's aims and victories: They are mere puppets in God's hands (W.A. 19:207). 
In this regard, there were also no discrepancies between Luther's understandings of creation and the work of Christ (recreation). Although (in our experience) God has many faces, somehow these faces coincide in the revelation in Jesus Christ (cf. also Durand 2007:3). In Luther's mind, the humanity of Christ is also, and indeed par excellence, a larva dei. The eternal God is veiled behind the broken body of Christ. Christ dons our masks (of dishonesty and sinful empowerment) and is crucified for this, for the sake of our unmasking. Here, wisdom (sapientia) means to see further than the broken body, or rather to discover the presence of God in this broken body - to discern the power of this vulnerable God. Therefore, Luther could also state that the unity of Christ's humanity and divinity is so complete that, in this instance, God himself is the mask behind which He hides (W.A., 4:7)!

We indeed need wisdom and discernment, to discover (reframe the perspective on) the God behind the multitude of masks in history. The problem arises when we suffer from the illusion that God's masks are (always) equal to himself, or worse, when we endeavour to put on this (godly) mask ourselves - as an act of self-empowering as described above. According to Luther, human beings suffer from exactly this perpetual affliction - to want to be part of God, or even God himself (W.A. 19:207).

Perhaps some interpretations of South African history are of interest here. A pertinent example would be how many (mostly white) South Africans understand the meaning of what is called the Day of the Covenant. This refers to a religious festival upheld by a section of the Afrikaner people, celebrating their ancestors' victory on the battlefield against all odds against the Zulu people at Blood River. God was given the honour for this, and a covenant was made to celebrate this day as a Sabbath. Currently, it is a public holiday known as the Day of Reconciliation (16 December).

For many years, the underlying "theological" interpretation of this was, and to a certain extent still is that God was with us. He revealed himself to us - the Afrikaner people. He was/is on our side. In terms of Luther, the question then would be: Was this - in terms of the experiences of the Voortrekkers a masked appearance of God himself? Or has it perhaps become a ritual through which the "mask" of God is mistaken as God himself? Was he not with the Zulu people when they lost and were killed in their thousands? On whose side is God today? Can we in fact locate Him on (any) side, thus putting on his mask to assure his power?

A chilling reminder that these questions are still of great importance in the current South African debate is the following recent remark made by President Jacob Zuma during a worship service of the Rhema Bible Church, where he was invited to speak - to the dismay of many South Africans, and obviously, other political parties: "God is on the side of the ANC." Religious- 
political rhetoric like this illustrates clearly that people, movements or ideologies easily tend to "mask" themselves with (the power of) God himself.

In my opinion, the role of preaching as an act of unmasking becomes indispensable here. Preaching not only reveals our true, vulnerable selves beneath or behind our masks and not only disempowers in the sense that it exposes our masking-for-power. Ultimately, it helps us to make sense of our experiences of God's masked appearances in our midst. That is to say, it helps us to let God be God, as deus revelatus (God revealed), but also deus incognito (God hidden away).

This is for our own good. In fact, we cannot look God in the face, for, who can see God and live? On the grounds of his love, God wears masks. We need God's masks to be able to approach him; but we must also be constantly reminded that God is more than his masks. In this sense, the act of unmasking is always ambiguous: It not only reveals (that God is behind his masks, and therefore more than his masks), but also simultaneously conceals (reminding us that God must remain behind these masks, because that is the only way in which he can approach us, and we him). Preaching takes masks away but, if necessary, also puts them back, reminding us that God's revelation is at the same time concealment, and that his concealment is at the same time revelation. Preaching of this nature reminds us of the paradoxical mode of God's revelation: God is present contrary to (para) the appearance (doxa) of the opposite (Berkhof 1979:54).

Preaching as masking and unmasking corresponds with the ambiguities of life, but at a deeper level, also with the ambiguities of the way in which God's presence is experienced in our midst. We know enough to make us laugh, and yet we know so little that we could cry. We see God's presence in our midst, and this brings a smile to our lips; yet we see only in a hazy mirror, and this brings tears to our eyes. We often laugh through our tears, or cry until we laugh. Often we wear the mask of laughter because of our experiences of the present God, but often the flipside of that mask depicts exactly the opposite: our tearful longings because of our experiences of the absent God.

In conjunction with the experience of the masquerade of God's revelation, Luther also often spoke of the playful nature of God, of him being a playful God (deus ludens; W.A. 4:656). Masks and play belong together. God playfully reveals himself, just to playfully conceal himself. He does not allow us to capture him in time; to encapsulate him in safe and secure dogmas or monumentalised myths. He is the living, playful God. To discern his presence, you need the art of timing the event. You need the grace of kairos. The present of his presence is a gift, not a nationalistic, political, ideological 
or theological strategy to be used at mass rallies, claiming that "God is with us".

God's (elusive) presence indeed remains a gift. In this regard, Purcell refers to the phenomenon of "Eucharistic Time", which signifies "the presence of Transcendence" (2001:141-144). The Eucharist is not only a present event; it rather creates the present as present. It constitutes the present as a gift (present). It interprets the present time to make it the time of the present/gift; it calls for "time out", to transform "time in" into a kairos (cf. Cilliers 2009:32).

From time to time, God does show his face more clearly, albeit still behind a mask. He does this because he loves us, because He wants us to become playful with him. In fact, his masquerade is loving playfulness. Luther often told of his experience as a young boy, when a farmer who seemingly scared him off by scolding him revealed the true nature of this behaviour by calling Luther nearer after scolding him and offering a sausage that he had been concealing behind his back all the time! For Luther, this was a striking image of the playful God (dues ludens) who seeks playful humans (homo ludens). Perhaps it is also a metaphor for the playfulness (as opposed to "absolute certainty") that forms part of preaching as an act of revealing and concealing.

What then are the homiletical implications of the abovementioned? Six possible considerations are outlined briefly.

\section{FACING GOD: HOMILETICAL IMPLICATIONS}

- The fact that we experience God's presence as being elusive should not dampen our conviction to preach. On the contrary, (the good news is that God indeed reveals himself to us and faces us. The anthropomorphic expression is that the face (panim) of God articulates the mode of his revelation forcefully. In this face, the total personality of God becomes clear and his inner being is represented. This denotes his graceful closeness to us. The flipside is also true, however: The panim Jahwe can also be concealed or turned away, indicating that God remains a mystery, not open to our grasp (cf. Gen. 4:14; Psalm 104: 29, etc.). With this expression, Israel wanted to confirm that the relationship between God and humans are real, but that God is never bound to or restricted by his revelation to us (cf. Vriezen, 1966:228). Therefore, to enter the space of God's face does not primarily denote a physical space, but points towards the potential and mystery of an event of engagement. Of course, this engagement can take place in any given physical space (topos), but God's closeness (or concealment) cannot be declared in terms of physical categories of space. Our primordial sin could indeed be called the longing to encapsulate God in a given space; the yearning 
for absolute knowledge of God's face (libido theologica) - but God's face cannot be known or seen absolutely. Exactly this remains the problem and promise of preaching: On the one hand, God's face seems like a façade, or in the words of Levinas,

By the façade the thing that keeps its secret is exposed enclosed in its monumental essence and in its myth, in which it gleams like a splendor but does not deliver itself. It captivates by its grace as by magic, but does not reveal itself (Levinas 1969: 193).

On the other hand, however, God's face is more than a façade. It is indeed God's face. This is the good news that should be preached.

- The paradoxical nature of our experiences of God's revelation implies that we should be silent more often - rather than speak too hastily of God. We are reminded of Karl Barth's dilemma: On occasion, he presented a series of lectures to ministers and, inter alia, said,

We are theologians; therefore, we must speak about God. However, we are also humans and, as such, we cannot speak about God. We must know both - that we must speak about God but cannot - and, exactly because of that, pay homage to God. That is the actual anxiety of the ministers of the Word. All other things beside are child's play (Barth 1924:158; freely translated).

In view of our experiences of the elusiveness of God's presence, we need to rediscover the relationship between silence and words, and ultimately, the Word. Out of the silence comes God's Word. In Christ, the silence was, and continuously is, being split open:

The Word that appeared two thousand years ago was on the way to man from the beginning of time, and therefore from the very beginning there was a breach between silence and speech. The event of two thousand years ago was so miraculous that all silence from time immemorial was torn open by speech. Silence trembled in advance of the event and broke in two" (Picard 1948:30).

Trembling, torn open silence - that is the space where we should be waiting for the advent of the Word (Cilliers 2008a:26). Homiletics indeed needs lessons in the art of silence.

- Our experiences of the elusiveness of God's presence also imply that we must accept that our lives are often characterised by struggle and uncertainty. Therefore, faith is not only about (final) answers, but also primarily about questions and dialogue. We cannot, and should not, try to captivate God in our sermons or liturgies. In fact, 
the collective act of worship seems to be both the indispensable vehicle of presence and its destroyer. Presence dilutes itself into its own illusion whenever it is confused with a spatial or temporal location. When presence is 'guaranteed' to human senses or reason, it is no longer real presence... It is when presence escapes man's grasp that it surges, survives, or returns (Terrien 1978:476).

Both these sides of our experiences of God's actions with us must thus be maintained, i.e. his transcendence and his immanence. Indeed, God reveals himself in history, and this is no deceptive revelation, but his Being that he reveals to us; it is he himself who makes history in his revelation. Between God's Being and his revelation, there is no tension. Yet, God is also more than his revelation. God's reality is not dissolved in his work. Because he is more than his works, he can work. Because he is greater than his revelation and precedes it, he can reveal himself (Durand 1976:47). Neither has God, in his revelation, been given to us as manipulable in our hands. His Name remains a nameless Name (Miskotte 1965:99-111). Therefore, sermons are not neatly packaged solutions, but open-ended confessions about God. We must not perceive a sermon to be a final product that is produced like an article for the market; rather as a process, a development that has many points of contact, which is inclusive, with open arms. A sermon is not an end product, not a final finished-off speech that is $100 \%$ correct! Actually, we cannot "finish" sermons, at most shout from time to time about the encounter that we enjoyed with God in the biblical text. Sermons may have and even should have "holes" or "linguistic gaps" (Umberto Eco) in them, areas we do not fully understand but within which we can hear the whisperings of the present God (cf. Cilliers 2004:89). Preaching can never be much more than humble beginnings.

- Preaching can also never be separated from the yearning for God's presence, from prayer, and therefore a hermeneutics of expectation (cf. Cilliers 2008b:70). Ricoeur uses the concept "hearkening" (l'écoute) to refer to a pre-ethical form of obedience: Before you can do anything, you should listen. It represents a mode of being, before it can become a mode of doing. In this process of expectant listening, you are no longer in control, rather dependent on that which you receive. Ricoeur even takes a further step back: Before you can listen, you should be quiet the latter being the source of "hearkening and obedience" (cf. Snodgras 2002:29). The memory of God's presence fills us with hope for the future revelations of God:

To be aware of divine hiddenness is to remember a presence and to yearn for its return. The presence of an absence denies its negativity... Presence perceived in an epiphanic visitation, a theophany, or the invaded solitude of a prophetic vision was 'swift-lived', yet the 
acceptance of the promise it carried transformed those who received and obeyed the command. Faded presence became a memory and a hope, but it burnt into an alloy of inward certitude, which was emunah, 'faith'. When God no longer overwhelmed the senses of perception and concealed himself behind the adversity of historical existence, those who accepted the promise were still aware of God's nearness in the very veil of his seeming absence. For them, the center of life was a Deus absconditus atque praesens. (Terrien 1978: 321, 470).

- All of this call for a stronger link between preaching and the Eucharist:

The Eucharist is...'the paradigmatic figure of this presence-ofthe-absence of God outside of which faith would no longer be faith'... presence and absence form one ambivalent reality (Mitchell 2005:143).

By means of the Eucharist, we are inducted into the tension of faith in the present absent God, the already and the not yet. What is presented at the table is eaten, but never fully consumed; is given, but never comes into our grasp; is broken, but is never destroyed; divided amongst us all, but never depleted; is handed out, and yet it remains a never-ending source of life. In short, it is presence, and yet also absence.

It is our task, then, to embrace the iconic gift of Christ's Eucharistic presence trembling with joy and courage, while never forgetting our doubt and fear. We must learn to recognize the presence of the absence, the truth of that Stranger who, blessing and breaking bread in the lonely outposts of our lives, comes as close as our breath and body, only to vanish from our sight (Mitchell 2005:151).

- When we yearn for God's presence in preaching and expect his face to be turned towards us, we should beware, because seeing the Other always implies seeing the other. Facing God always includes facing the other. Levinas reminds us that

the epiphany of the face qua face opens humanity. The face in its nakedness as a face presents to me the destitution of the poor one and the stranger (Levinas 1969:213).

The Other never comes without the other. This paradoxical God image runs like a golden thread throughout the Bible. For instance, when Peter uses the idiomatic expression that God is like a father who judges all people impartially without favouritism (1 Peter 1:17), he links back to passages like Deuteronomy 10:17; 16:19 and Leviticus 19:15 where we literally hear that God "does not lay hold of someone's face", i.e. that he "does not esteem anyone according to face value" (cf. also Mat. 22:16; Mark 12:14; Luke 
20:21; Acts 10:34; Rom. 2:11; Gal. 2:6; Col. 3:25; Eph. 6:9, etc.). This refers to the context of slavery, when masters, when buying slaves, would lift up the slave's face (who was not allowed to look anyone in the eye), to evaluate the health, ability and countenance - literally the face value. It is a phrase taken from the sphere of complete power versus total powerlessness. When this phrase occurs in the Bible, it is almost always in a context that emphasises God's sovereignty and power. However, in contrast to the often dominating and abusive power of authorities, for instance slave masters, the essence of God's power is defined in terms of loving care and concern for people, particularly by God's restoring what was lost to them - their dignity and humanity. God does this up the point where he is stripped of his own dignity and humanity in Christ. It is exactly here - in the seemingly total absence of any form of divinity - that God is present. Ultimately, it is this "absent presence" of God in Christ that forms the crux of our preaching.

\section{BIBLIOGRAPHY}

BARTH, K.

1924. Not und Verheissung der Christlichen Verkündigung. (Das Wort Gottes und die Theologie. Gesammelte Vorträge). München: Kaiser.

BERKHOF, $\mathrm{H}$.

1979. Christian Faith. Grand Rapids: Eerdmans.

BOHREN, R.

1972. Predigtlehre. München: Kaiser Verlag.

CILLIERS, J.H.

2004. The living voice of the gospel. Revisiting the basic principles of preaching. Stellenbosch: Sun Press.

2008a. Silence is golden: Liturgy beyond the edge of language. Praktiese Teologie in Suid-Afrika Vol 23 (1) 2008:19-35.

2008b. Skrifbeskouing en Skrifhantering: Perspektiewe op ' $n$ hermeneutiek van verwagting. Verbum et Ecclesia. Volume 29 (1) 2008:62-76.

2009. Time out. Perspectives on liturgical temporality. NGTT. Deel 50 (1 en 2):2635.

DURAND, J.

2007. The many faces of God: Highways and byways on the route towards an orthodox image of God in the history of Christianity from the first to the seventeenth century. Stellenbosch: Sun Press.

DURAND, J.J.F.

1976. Die Lewende God. Pretoria: NG Kerkboekhandel. 
KieRKEgaARD, S.

1949. Die Tagebücher, 1834-1855. München: Kösel.

LEVINAS, E.

1969. Totality and Infinity. An Essay on Exteriority. Translated by Alphonso Lingis. Pittsburgh, Pennsylvania: Duquesne University Press.

LUTHER, M.

1883. Weimarer Ausgabe (WA). Baden-Baden: Heitz.

McGRath, A.E.

1985. Luther's theology of the Cross: Martin Luther's theological breakthrough. Oxford: Blackwell.

Miskotte, K.H.

1965. Als de goden zwijgen. Haarlem: Callenbach.

MITCHELL, N.D.

2005. Mystery and Manners: Eucharist in Post-Modern Theology. Worship 79(2), March 2005: 30-151.

Neven, G.W.

2009. De Kwintessens van Calvijn. In: R.R. Brouwer, B. De Leede \& K. Spronk (red.), Het calvinistisch ongemak. Calvijn als erflater en provocator van het Nederlandse protestantisme (Kampen:Kok), pp. 73-97.

Picard, M.

1948. The World of silence. London: The Harvill Press.

Purcell, M.

2001. "This Is My Body" Which Is "For You"... Ethically Speaking. In: L. Boeve \& J.C. Ries (eds.), The Presence of Transcendence. Thinking 'Sacrament' in a Postmodern Age (Leuven - Paris - Sterling, VA: Peeters), pp.135-152.

ShaKespeare, W.

1914. The tragedy of Macbeth. The Harvard Classics. Harvard: Harvard University Press.

SNODGRASS, K.

2002. Reading to hear: A hermeneutics of hearing. Horizons in Biblical Theology 24:1-32.

Stolt, B.

2000. Martin Luthers Rhetorik des Herzens. Tübingen: Mohr Siebeck

TERRIEN, S.

1978. The Elusive Presence. Toward a New Biblical Theology. San Francisco: Harper and Row.

Van Der Kool, C.

2002. Als in een Spiegel. God kennen volgens Calvijn en Barth. Kampen: Kok. 
Acta Theologica

Van Gennep, A.

1909. Les rites de passage. Paris: Emile Nourry.

VRiezen, T.C.

1966. Hoofdlijnen der theologie van het Oude Testament. Wageningen: H Veenman en Zonen N.V.

Trefwoorde

Openbaring

Teenwoordigheid

Afwesigheid

Maskers
Keywords

Revelation

Presence

Absence

Masks 